\title{
Evaluation of Bacterial Profile and Drug Resistance Patterns of Blood Culture Isolates in Amir Al-Momenin Hospital of Gerash, Iran
}

\author{
Iran, Gerash Amir Al-Momenin Hastanesi'nde Kan Kültürü Izolatlarının Bakteriyel Profili ve Illaç \\ Direnç Modellerinin Değerlendirilmesi
}

\section{(1) Abbas FARAHANI ${ }^{1}$, (1) Armaghan Vaez LARI ${ }^{2}$, (1) Hossein FOROUZANDEH ${ }^{3}$, (1) Jebreil SHAMSEDDIN ${ }^{1}$, (1) Hossein HAFEZI ${ }^{4}$, (1) Iraj AHMADI ${ }^{5}$, (1) Kusar ZAREBI ${ }^{6}$, (1) Parisa MOHSENI ${ }^{7}$, (1) Zahra FOROUZANDEH ${ }^{8}$, (1) Fatemeh FARIYABI ${ }^{9}$}

1 Infectious and Tropical Diseases Research Center, Hormozgan Health Institute, Hormozgan University of Medical Sciences, Bandar Abbas, Iran ${ }^{2}$ Ahvaz Jundishapur University of Medical Sciences, Faculty of Medicine, Department of Physiology, Ahvaz, Iran

${ }^{3}$ Cellular and Molecular Research Center, Gerash University of Medical Sciences, Gerash, Iran

${ }^{4}$ Hormozgan University of Medical Sciences, Department of Dermatology, Bandar Abbas, Iran

5 Ilam University of Medical Sciences, Faculty of Medicine, Department of Physiology, Ilam, Iran

${ }^{6}$ Blood Transfusion Research Center, High Institute for Research and Education in Transfusion Medicine; Student Research Committee, Public Health Department, School of Public Health and Safety, Shiraz University of Medical Sciences, Shiraz, Iran

7Student Research Committee, Department of Epidemiology, School of Public Health and Safety, Shahid Beheshti University of Medical Sciences, Tehran, Iran

8 Jahrom University of Medical Sciences, Department of Nursing, Jahrom, Iran

${ }^{9}$ Cellular and Molecular Research Center, Gerash University of Medical Sciences, Gerash, Iran

\section{Abstract}

Introduction: Bacterial bloodstream diseases cause important public health problems and are considered as significant issues in morbidity and mortality in patients who are hospitalized. This study aimed to investigate the frequency of bacterial isolates from suspected septicemia and subsequent drug resistance patterns in affiliated patients to the Amir Al-Momenin Hospital of Gerash, Fars, Iran.

Materials and Methods: In this hospital-based cross-sectional study, 2485 blood samples were examined in the Bacteriology Laboratory of Amir AlMomenin Hospital of Gerash, during 2018-2019. Then, drug susceptibility tests were done for positive blood cultures. All specimens were cultivated in MacConkey agar, Blood Agar, and chocolate agar mediums. A total of 120 positive samples were obtained, and biochemical tests were used to classify bacteria to species levels. After identification, a drug susceptibility test was carried out on the Mueller-Hinton agar via 16 antibiotics based on the Clinical and Laboratory Standards Institute guidelines.

Results: Of the 2485 blood culture results, 120 (4.82\%) were determined as positive. The blood culture examination revealed the most common isolated as Staphylococcus epidermidis (45\%, $\mathrm{n}=54$ cases), Acinetobacter baumannii (10.83\%, $\mathrm{n}=13$ cases), Escherichia coli (10\%, $\mathrm{n}=12$ cases), Klebsiella pneumoniae (5.83\%, $\mathrm{n}=7$ cases), respectively. Additionally, among all the antibiotics tested, the highest percentage of resistance was related to cefoxitin in 48 cases (40\%), cephalexin in 47 (39.1\%), clindamycin in 47 (39.1\%), and erythromycin in 42 (35\%).

Conclusions: Results revealed that most of the bacterial isolates had a high rate of resistance to the most commonly used antibiotics. Therefore, continuous antibiotic resistance pattern evaluation in different areas is necessary.

Keywords: Bloodstream infection, antimicrobial susceptibility pattern, drug resistance, bacterial isolates 
Giriş: Bakteriyel kan dolaşımı hastalıkları önemli halk sağlığı sorunlarına neden olur ve hastanede yatan hastalarda morbidite ve mortalite açısından önemli sorunlar olarak kabul edilir. Bu çalışma, İran, Fars, Gerash'taki Amir Al-Momenin Hastanesi'nden takipli hastalar içerisinde septisemi şüphesi olan hastalardaki bakteriyel izolatların sıklığını ve ardından ilaç direnç modellerini araştırmayı amaçladı.

Gereç ve Yöntem: Bu retrospektif tanımlayıcı çalışmada; 2018-2019 yılları arasında Gerash Amir Al-Momenin Hastanesi Bakteriyoloji Laboratuvarı'nda 2485 kan örneği incelendi. Ardından pozitif kan kültürleri için ilaç duyarlılık testleri yapıldı. Tüm örnekler MacConkey agar, Blood Agar ve çikolata agar besiyerlerine yetiştirildi. Yüz yirmi pozitif örnek alındı ve bakterileri tür seviyelerine göre sınıflandırmak için biyokimyasal testler kullanıldı. Tanımlamadan sonar, Mueller-Hinton agar üzerinde Klinik ve Laboratuvar Standartları Enstitüsü (CLSI) kılavuzlarına dayalı olarak 17 antibiyotik ile ilaç duyarlılık testi yapıldı.

Bulgular: Toplam 2485 kan kültürü sonucunun 120'si $(\% 4,82)$ pozitif olarak belirlendi. Kan kültürleri incelendiğinde en sık izole edilen etkenler; Staphylococcus epidermidis (\%45, n=54), Acinetobacter baumannii $(\% 10.83, \mathrm{n}=13)$, Escherichia coli $(\% 10, \mathrm{n}=12)$ ve Klebsiella pneumoniae $(\% 5,83$, $\mathrm{n}=7)$ idi. Ayrıca, test edilen tüm antibiyotikler arasında en yüksek direnç $48(\% 40)$ hasta ile sefoksitinde görüldü. Sonra sırasıyla; $47(\% 39,1)$ hastada ile sefaleksin, $47(\% 39,1)$ hastada klindamisin ve $42(\% 35)$ hastada eritromisin direnci saptandı.

Sonuç: Bulgular, bakteri izolatlarının çoğunun en sık kullanılan antibiyotiklere karşı yüksek oranda direnç gösterdiğini göstermektedir. Bu nedenle, farklı alanlarda antibiyotik direnç paternlerinin sürekli değerlendirilmesi gereklidir.

Anahtar Kelimeler: Kan dolaşımı enfeksiyonu, antimikrobiyal duyarlııı paterni, ilaç direnci, bakteriyel izolatlar

\section{Introduction}

Septicemia or blood infection is one of the most important causes of morbidity and mortality worldwide and is considered as medical urgency, with treatment that should be performed in hospitals even in intensive care units (ICU) ${ }^{[1,2]}$. Bloodstream infections are responsible for $10-20 \%$ of all nosocomial infections and are classified as leading causes of death in the United States ${ }^{[3]}$. Approximately 20,000 cases of bacteremia occur periodically, with mortality rates of $20-50 \%$ worldwide ${ }^{[1]}$. The United States reported mortality rate related to septicemia as $14-37 \%{ }^{[4]}$.

Moreover, its prevalence in Southeast Asia has increased from 16.7 in 2001 to 38.1 per 100,000 people in 2010 ${ }^{[5]}$. A broad spectrum of Gram-negative and Gram-positive bacteria can cause blood infections ${ }^{[6]}$. Blood sample cultivation is the most common method for blood infection diagnosis. Such patients should be immediately initiated with antibiotic therapy after blood cultures.

Microbial susceptibility pattern information in society, hospitals, and patients is important to pay attention to. Moreover, bacterial infection prevalence awareness and their antibiotic susceptibilities play a vital role in the prescription of appropriate medications ${ }^{[1]}$. Early diagnosis and appropriate treatment or delayed recognition of these infections differentiate between life and death ${ }^{[7]}$; thus, rapid bacterial pathogen identification and timely appropriate treatment initiation is the only way to treat bacteremia at the moment ${ }^{[8]}$. Several bacterial pathogens have displayed antibiotic resistance, which has led to economic and social burdens worldwide and become serious public health concerns ${ }^{[9]}$. Blood infections often occur during the hospitalization period and raise health care costs and losses. Many studies have shown that inappropriate treatment of bacterial infections is associated with adverse effects, including increased drug resistance and mortality rates ${ }^{[10]}$. Identifying the bacterial diversity of blood infections and their antibiotic resistance patterns is important. Therefore, this study aimed to investigate the bacterial agents and their drug resistance patterns in blood cultures of affiliated patients to Amir alMomenin Hospital in Garash, Fars, Iran in 2018-2019.

\section{Materials and Methods}

\section{Bacteria Isolation and Blood Culture}

This hospital-based cross-sectional study was performed in Amir-al-Momenin Hospital of Grash (Central Hospital in the south of Fars province, Iran) for 12 months from August 2018 to July 2019, wherein a total of 2485 blood samples from patients with clinically suspected septicemia were examined in the Bacteriology Laboratory of the Hospital.

Two blood samples were taken ( $5 \mathrm{ml}$ from two different sites) under the aseptic conditions from clinically diagnosed septicemia cases for routine blood culture before antibiotic therapy initiation. The venepuncture site was correctly disinfected with $2 \%$ tincture of iodine and 70\% alcohol before taking $10 \mathrm{ml}$ of blood for cultivation. Approximately $5 \mathrm{ml}$ of venous blood was added into $50 \mathrm{ml}$ of Brain Heart Infusion broth (HiMedia, India) and was aerobically incubated at $37{ }^{\circ} \mathrm{C}$ for 10 days. Subculture and identification of isolates were done on chocolate agar, 5\% sheep blood agar, and MacConkey agar after 24 h, 48 h, 5 days, and 10 days.

Note the MacConkey agar plate was incubated in aerobic condition, whereas blood and chocolate agar plates were incubated in the microaerophilic atmosphere using a candle jar $\left(5-10 \% \mathrm{CO}_{2}\right)$. 
Bacterial isolates were diagnosed by their morphologic appearances (such as Gram staining, colony shape) and biochemical tests to identify bacteria to species levels. Coagulase, catalase, optochin, novobiocin susceptibility tests, Christie, Atkinson, Munch, Peterson test (for Streptococcus agalactiae), and Esculin agar (for Enterococci) were implemented to determine Gram-positive bacteria, whereas citrate, indole, motility, triple sugar iron, lysine decarboxylase, urea and oxidase (for Pseudomonaceae) were performed or Enterobacteriaceae members, formerly Enterobacteriaceae, and other Gramnegative bacteria ${ }^{[11]}$.

\section{Antimicrobial Susceptibility Tests}

Antimicrobial susceptibility tests for all blood cultures were done via Mueller-Hinton agar (Oxoid, Hampshire, UK) using Kirby-Bauer disc diffusion method as per Clinical and Laboratory Standards Institute (2019) guidelines ${ }^{[12]}$.

The antibiotics discs were obtained from MAST company (MAST, Group Ltd., Merseyside, UK) in the following concentrations: ampicillin (AM, $10 \mu \mathrm{g})$, amikacin (AN, $30 \mu \mathrm{g})$, cefixime (CFE, $30 \mu \mathrm{g})$, imipenem (IPM, $10 \mu \mathrm{g})$, ciprofloxacin (CP, $5 \mu \mathrm{g})$, ceftazidime $(\mathrm{CAZ}, 30 \mu \mathrm{g})$, gentamicin $(\mathrm{GM}, 10 \mu \mathrm{g})$, co-trimoxazole (SXT, 1.25/23.75 $\mu \mathrm{g}$ ), erythromycin ( $\mathrm{E}, 15 \mu \mathrm{g})$, cefoxitin (FOX, $30 \mu \mathrm{g})$, penicillin ( $\mathrm{P}, 10$ units), cefotaxime (CTX, $30 \mu \mathrm{g})$, clindamycin (CC, $2 \mu \mathrm{g})$, cephalexin $(\mathrm{CN}, 30 \mu \mathrm{g})$, ceftriaxone (CRO, $30 \mu \mathrm{g})$, and levofloxacin (LEV, $5 \mu \mathrm{g}$ ).

Staphylococcus aureus (ATCC 25923), Pseudomonas aeroginosa (ATCC 27853), and Escherichia coli (ATCC 25922) were used as reference strains for culture and drug susceptibility tests.

\section{Ethics Clearance}

The Ethics Committee of Gerash University of Medical Sciences, Gerash, Iran, approved this study with reference number IR.GERUMS.REC.1400.021.

\section{Data Analysis}

Statistical analyses were done by Statistical Package for the Social Sciences software version 25 (IBM, Chicago, IL, USA). All data were prepared as percentages and frequencies for a basic description. Statistical analyses were performed using the chisquare test, and a $p$ value of $\leq 0.05$ was considered statistically significant.

\section{Results}

\section{Culture and Isolation}

This study revealed $120(4.82 \%)$ patients with positive blood cultures out of 2485 blood culture results. Among total cases, $50 \%$ ( $n=60$ cases) and 50\% ( $n=60$ cases) were females and males, respectively.

Blood culture examinations revealed that the most common isolated organisms were Staphylococcus epidermidis ( $S$. epidermidis) (45\%, $\mathrm{n}=54$ cases), Acinetobacter baumannii ( $A$. baumannii) (10.83\%, $\mathrm{n}=13$ cases), Escherichia coli (E. coli) $(10 \%, n=12$ cases), Klebsiella pneumoniae (5.83\%, $n=7$ cases), respectively. Other isolated microorganisms are shown in Figure 1.

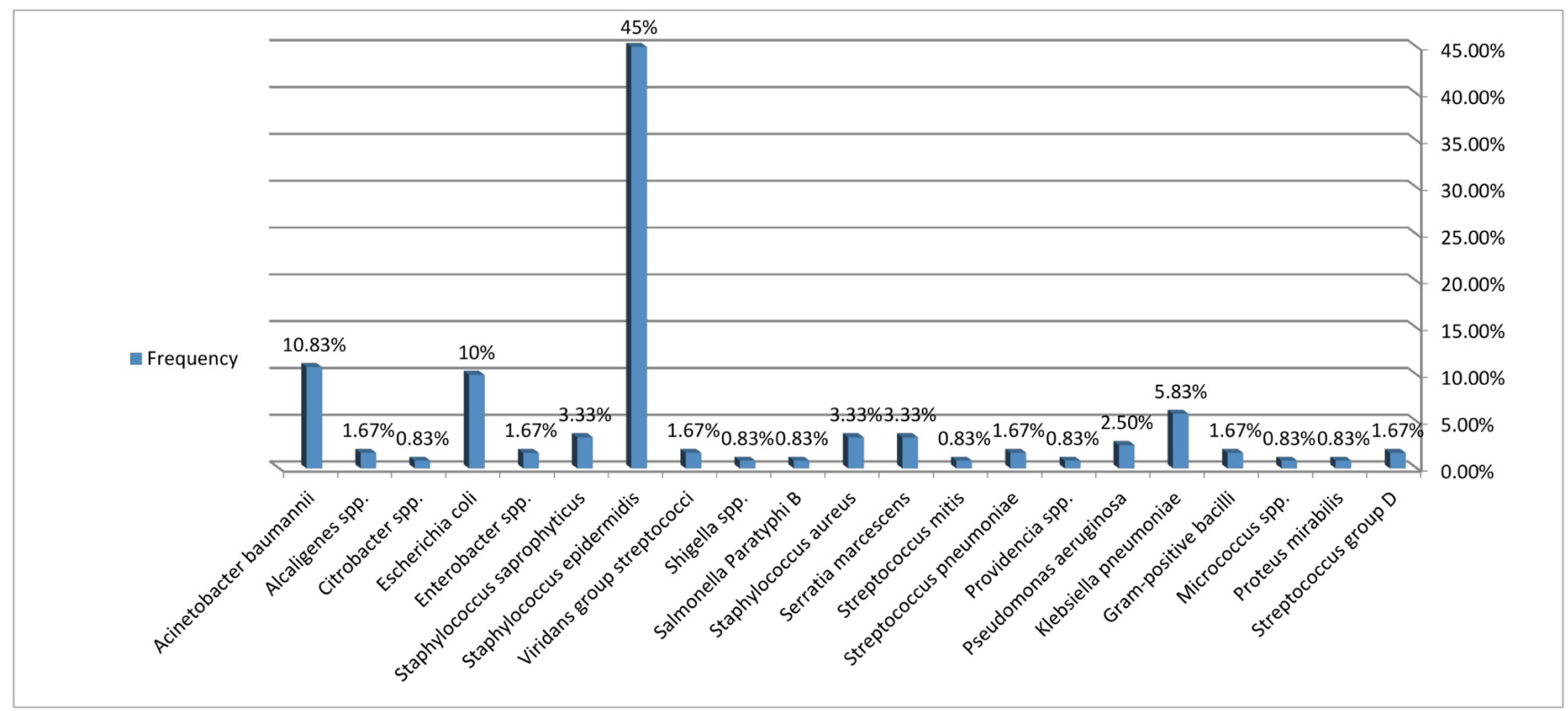

Figure 1. Bacterial isolates collected from blood culture 
Moreover, patients with positive blood cultures were classified based on inpatient wards. The current study revealed the most cases of septicemia in the emergency (ER) ward with 53 cases (44.17\%), pediatric ward with 25 (20.83\%), neonatal ICU (NICU) with 14 (11.67\%), internal medicine with 10 cases (8.33\%), ICU with eight cases (6.67\%), and outpatient (OPD) and surgical wards with five cases (4.17\%), respectively (Figure 2).

S. epidermidis (15\%), A. baumannii (7.5\%), and E. coli (5.83\%) were the most common causes of blood infections in the ER ward, respectively, whereas S. epidermidis (3.33\%) and $A$. baumannii $(0.83 \%)$ in the OPD ward; S. epidermidis $(\mathrm{n}=3$, $2.5 \%)$ and Serratia marcescens $(n=2,1.67 \%)$ in the ICU ward; S. epidermidis $(n=3,2.5 \%)$ and E. coli $(n=2,1.67 \%)$ in the internal ward; S. epidermidis $(n=18,15 \%)$ in the pediatrics ward; S. epidermidis $(\mathrm{n}=1,0.83 \%)$, Klebsiella pneumoniae $(\mathrm{n}=1$, $0.83 \%)$, E. coli $(n=1,0.83 \%)$, and Alcaligenes spp. $(n=1,0.83 \%)$ in surgery ward; S. epidermidis $(\mathrm{n}=7,5.83 \%)$, Pseudomonas aeruginosa $(n=2,1.67 \%)$, and Staphylococcus saprophyticus $(n=2,1.67 \%)$ in the NICU ward. Generally, S. epidermidis was the most prevalent isolated bacteria from different parts of the hospital (Table 1).

Moreover, septicemia in males and females was equal [60 (50\%) of males and 60 (50\%) of females]. No significant relationship was determined between gender and blood infections $(p>0.05)$.

\section{Antibiotic Susceptibility}

S. epidermidis isolates were resistant to CN (83.3\%), FOX (83.3\%), CC (81.5\%), and P (75.9\%) antibiotics, respectively.

Results of antimicrobial susceptibility testing showed that $\geq 38.5 \%$ of $A$. baumannii isolates were non-susceptible to CTX, $\mathrm{CFE}, \mathrm{AM}$, and CAZ. E. coli isolates were resistant to LEV (41.6\%), IPM (33.3\%), and CFE (33.3\%) antibiotics, respectively. Results of antibiotic susceptibility for other isolates of blood cultures are presented in Tables 2 and 3. Additionally, among all the tested antibiotics, the highest percentage of resistance was related to FOX with 48 cases (40\%), CN with 47 cases (39.1\%), CC with 47 cases (39.1\%), and E with 42 cases (35\%).

\section{Discussion}

Today, despite significant advances in health, antimicrobial, and supportive therapies, septicemia remains a life-threatening factor. Causative agent isolation in blood culture is essential for proper antibiotic treatment ${ }^{[13]}$. Different organisms have different sensitivities to antibiotics and successful treatment relies on appropriate drug administration. Delayed treatment and inappropriate use may lead to antibiotic resistance ${ }^{[14]}$. This study was conducted in the Amir-al-Momenin teaching hospital of Garash, Iran, for 12 months. Of the 2485 blood cultures, 120 $(4.82 \%)$ were detected as positive.

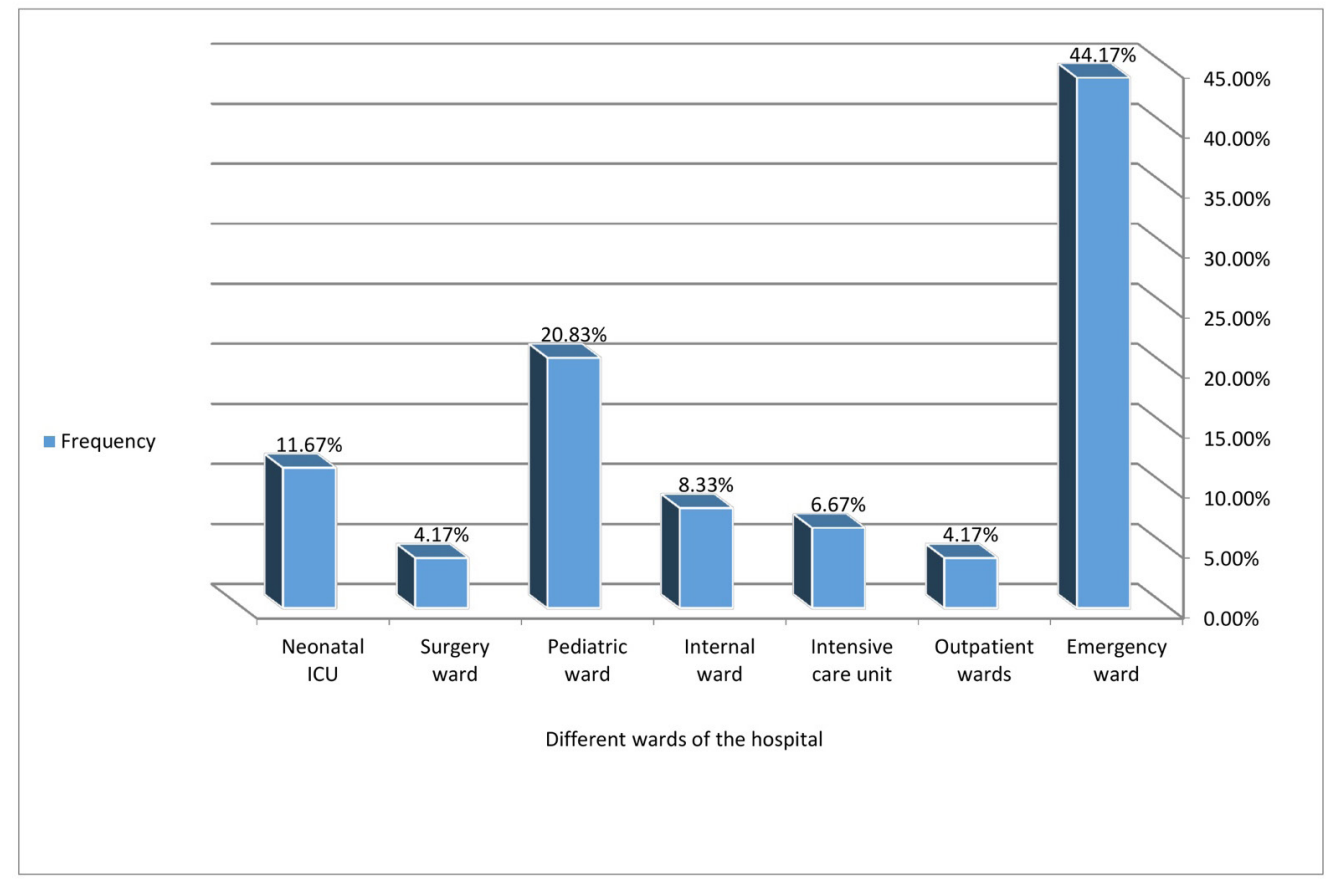

Figure 2. Investigation of the different wards of the hospital in terms of blood infection prevalence 
Table 1. Results of blood culture based on a hospital ward

\begin{tabular}{|c|c|c|c|c|c|c|c|c|}
\hline Result culture & & Department & & & & & & \\
\hline Isolates & Total isolate & ER & OPD & ICU & Internal & Pediatric & Surgery & $\mathrm{NICU}$ \\
\hline Acinetobacter baumannii & $13(10.83 \%)$ & $9(7.5 \%)$ & $1(0.83 \%)$ & $0(0.0 \%)$ & $1(0.83 \%)$ & $1(0.83 \%)$ & $0(0.0 \%)$ & $1(0.83 \%)$ \\
\hline Alcaligenes spp. & $2(1.67 \%)$ & $0(0.0 \%)$ & $0(0.0 \%)$ & $0(0.0 \%)$ & $1(0.83 \%)$ & $0(0.0 \%)$ & $1(0.83 \%)$ & $0(0.0 \%)$ \\
\hline Citrobacter spp. & $1(0.83 \%)$ & $1(0.8 \%)$ & $0(0.0 \%)$ & $0(0.0 \%)$ & $0(0.0 \%)$ & $0(0.0 \%)$ & $0(0.0 \%)$ & $0(0.0 \%)$ \\
\hline E. coli & $12(10 \%)$ & $7(5.83 \%)$ & $0(0.0 \%)$ & $1(0.83 \%)$ & $2(1.67 \%)$ & $1(0.83 \%)$ & $1(0.83 \%)$ & $0(0.0 \%)$ \\
\hline Enterobacter spp. & $2(1.67 \%)$ & $1(0.83 \%)$ & $0(0.0 \%)$ & $0(0.0 \%)$ & $0(0.0 \%)$ & $0(0.0 \%)$ & $0(0.0 \%)$ & $1(0.83 \%)$ \\
\hline $\begin{array}{l}\text { Staphylococcus } \\
\text { saprophyticus }\end{array}$ & $4(3.33 \%)$ & $0(0.0 \%)$ & $0(0.0 \%)$ & $1(0.83 \%)$ & $0(0.0 \%)$ & $1(0.83 \%)$ & $0(0.0 \%)$ & $2(1.67 \%)$ \\
\hline Staphylococcus epidermidis & $54(45 \%)$ & $18(15.0 \%)$ & $4(3.33 \%)$ & $3(2.5 \%)$ & $3(2.5 \%)$ & $18(15.0 \%)$ & $1(0.83 \%)$ & 7 (5.83\%) \\
\hline Viridans Streptococci & $2(1.67 \%)$ & $1(0.83 \%)$ & $0(0.0 \%)$ & $0(0.0 \%)$ & $0(0.0 \%)$ & $1(0.83 \%)$ & $0(0.0 \%)$ & $0(0.0 \%)$ \\
\hline Shigella spp. & $1(0.83 \%)$ & $1(0.83 \%)$ & $0(0.0 \%)$ & $0(0.0 \%)$ & $0(0.0 \%)$ & $0(0.0 \%)$ & $0(0.0 \%)$ & $0(0.0 \%)$ \\
\hline $\begin{array}{l}\text { Salmonella enterica Serovar } \\
\text { Paratyphi B }\end{array}$ & $1(0.83 \%)$ & $1(0.83 \%)$ & $0(0.0 \%)$ & $0(0.0 \%)$ & $0(0.0 \%)$ & $0(0.0 \%)$ & $0(0.0 \%)$ & $0(0.0 \%)$ \\
\hline Staphylococcus aureus & $4(3.33 \%)$ & $3(2.5 \%)$ & $0(0.0 \%)$ & $0(0.0 \%)$ & $0(0.0 \%)$ & $1(0.83 \%)$ & $0(0.0 \%)$ & $0(0.0 \%)$ \\
\hline Serratia marcescens & $4(3.33 \%)$ & $2(1.67 \%)$ & $0(0.0 \%)$ & $2(1.67 \%)$ & $0(0.0 \%)$ & $0(0.0 \%)$ & $0(0.0 \%)$ & $0(0.0 \%)$ \\
\hline Streptococcus mitis & $1(0.83 \%)$ & $0(0.0 \%)$ & $0(0.0 \%)$ & $0(0.0 \%)$ & $0(0.0 \%)$ & $1(0.83 \%)$ & $0(0.0 \%)$ & $0(0.0 \%)$ \\
\hline Streptococcus pneumoniae & $2(1.67 \%)$ & $2(1.67 \%)$ & $0(0.0 \%)$ & $0(0.0 \%)$ & $0(0.0 \%)$ & $0(0.0 \%)$ & $0(0.0 \%)$ & $0(0.0 \%)$ \\
\hline Providencia spp. & $1(0.83 \%)$ & $0(0.0 \%)$ & $0(0.0 \%)$ & $0(0.0 \%)$ & $1(0.83 \%)$ & $0(0.0 \%)$ & $0(0.0 \%)$ & $0(0.0 \%)$ \\
\hline Pseudomonas aeruginosa & $3(2.5 \%)$ & $1(0.83 \%)$ & $0(0.0 \%)$ & $0(0.0 \%)$ & $0(0.0 \%)$ & $0(0.0 \%)$ & $0(0.0 \%)$ & $2(1.67 \%)$ \\
\hline Klebsiella pneumoniae & $7(5.83 \%)$ & $4(3.33 \%)$ & $0(0.0 \%)$ & $0(0.0 \%)$ & $0(0.0 \%)$ & $1(0.83 \%)$ & $1(0.83 \%)$ & $1(0.83 \%)$ \\
\hline Gram-positive bacilli & $2(1.67 \%)$ & $0(0.0 \%)$ & $0(0.0 \%)$ & $0(0.0 \%)$ & $1(0.83 \%)$ & $0(0.0 \%)$ & $1(0.83 \%)$ & $0(0.0 \%)$ \\
\hline Micrococcus spp. & $1(0.83 \%)$ & $1(0.83 \%)$ & $0(0.0 \%)$ & $0(0.0 \%)$ & $0(0.0 \%)$ & $0(0.0 \%)$ & $0(0.0 \%)$ & $0(0.0 \%)$ \\
\hline Proteus mirabilis & $1(0.83 \%)$ & $0(0.0 \%)$ & $0(0.0 \%)$ & $1(0.83 \%)$ & $0(0.0 \%)$ & $0(0.0 \%)$ & $0(0.0 \%)$ & $0(0.0 \%)$ \\
\hline Streptococcus Group D & $2(1.67 \%)$ & $1(0.83 \%)$ & $0(0.0 \%)$ & $0(0.0 \%)$ & $1(0.83 \%)$ & $0(0.0 \%)$ & $0(0.0 \%)$ & $0(0.0 \%)$ \\
\hline Total & $120(100 \%)$ & $53(44.17 \%)$ & $5(4.17 \%)$ & $8(6.67 \%)$ & $10(8.33 \%)$ & $25(20.83 \%)$ & $5(4.17 \%)$ & $14(11.67 \%)$ \\
\hline
\end{tabular}

ER: Emergency ward, NICU: Neonatal intensive care unit, OPD: Outpatient wards, ICU: Intensive care unit

The most common blood infection causes in our study include S. epidermidis $(n=54,45 \%), A$. baumannii $(n=13,10.83 \%)$ and $E$. coli $(n=12,10 \%)$, respectively.

These findings are consistent with the study results by Sedigh et al. ${ }^{[15]}$ that evaluated pediatric bloodstream infections in Nemazee Hospital, Shiraz, Iran.

Of the 491 blood cultures, $74(15.1 \%)$ samples were identified as positive. Acinetobacter isolates (8.1\%) were found to be the most common Gram-negative isolates. Additionally, among the obtained Gram-positive cocci, S. epidermidis strains (48.6\%) were the predominant bacterial pathogens. Therefore, the most Gram-positive cocci were sensitive to vancomycin (98\%) and chloramphenicol (72.5\%). Further, the most effective antibiotics against Gram-negative isolates were chloramphenicol (30.4\%) and CP (47.8\%).

Moreover, several researchers have evaluated the bacterial profile and antimicrobial susceptibility pattern in patients with suspected septicemia in other parts of the world. A study conducted by Vaez et al. ${ }^{[16]}$ at Tehran Be'esat Hospital revealed that coagulase-negative staphylococci were the most frequent bacterium and Proteus was the least frequent among the 129 positive blood cultures.

Another study carried out by Dagnew et al. ${ }^{[1]}$ at Gondar University Hospital (Ethiopia) revealed that the dominant bacteria isolated from blood cultures were coagulase-negative staphylococci (42.3\%), S. aureus (23.9\%), Klebsiella spp. (9.12\%), E. coli (7\%), Pseudomonas aeroginosa (5.6\%), and Salmonella spp. (4.2\%), respectively.

The present study has an equal rate of septicemia in both genders, $60(50 \%)$ in males and $60(50 \%)$ in females. No significant relationship was observed between gender and bloodstream infections ( $p>0.05)$. Similarly, the study by Mahmoudi et al. ${ }^{[17]}$ revealed no significant relationship between gender and bloodstream infections.

The investigation performed by Dogru et al. ${ }^{[18]}$ in Turkey revealed the most frequently isolated microorganisms as Pseudomonas 


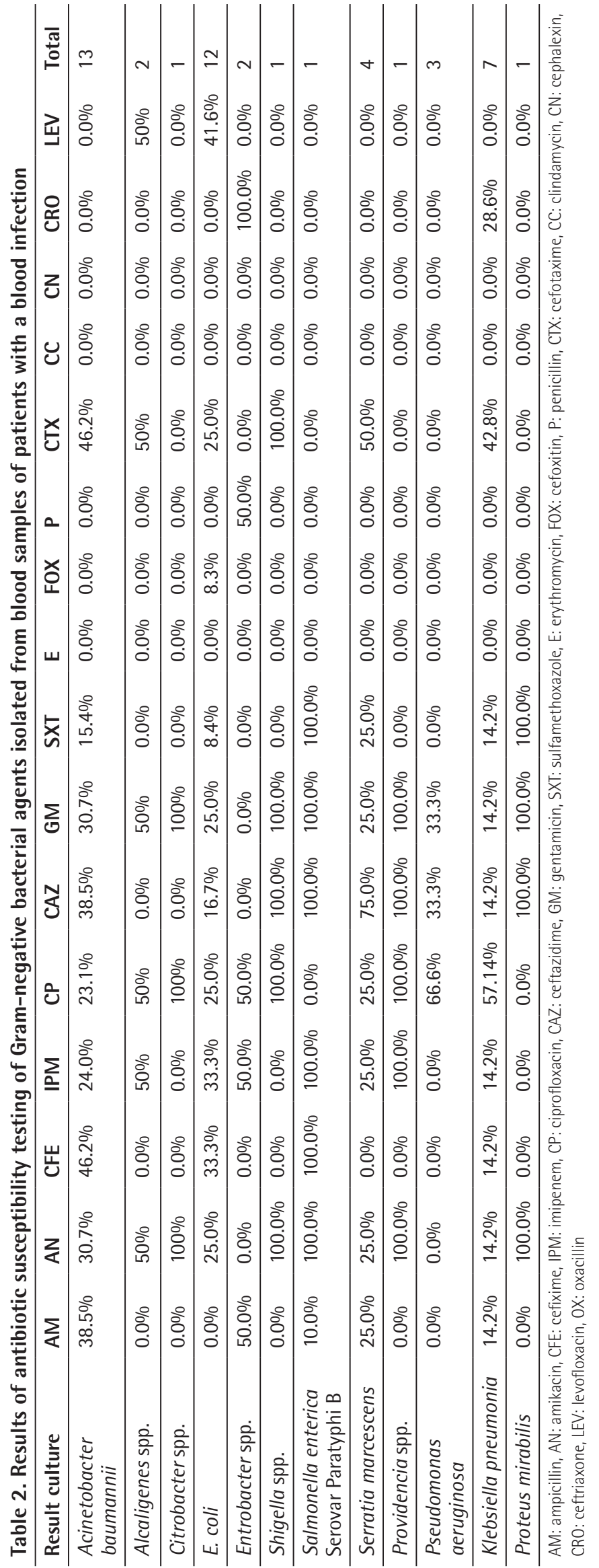

aeruginosa and Acinetobacter spp., and 43\% of infections were in females and $57 \%$ in males. This study was similar to ours and no significant relationship was determined between the prevalence of infection and gender ( $p>0.05)$. A common finding in these studies is the prevalence of Staphylococci in bloodstream infections, which is similar to our results.

Another study by Japoni et al. ${ }^{[19]}$ in Shiraz, Iran, revealed that the highest activity against Gram-negative bacteria was observed for IPM (96.1\%), CP (83\%), and AN (77.9\%), whereas for Grampositive isolates, vancomycin (98.4\%), chloramphenicol (86.4\%), and CP (77.4\%) were effective antibiotics. These findings indicated that the causative agents of bloodstream infections and their antibiotic susceptibility vary in different regions and periods. Thus, monitoring and detecting the bacterial pathogens from blood cultures are very important to manage the infection and therapeutic decisions. This finding can be helpful for clinicians to consider appropriate treatment.

The present study revealed that the highest cases of septicemia are in the ER ward (44.17\%), pediatric ward (20.83\%), NICU (11.67\%), internal medicine (8.33\%), ICU (6.67\%), and OPD and surgical wards (4.17\%), respectively. The study conducted by Mahmoudi et al. ${ }^{[1]]}$ revealed that the prevalence rate of septicemia in the pediatric ward with $40(20.51 \%)$, surgery with $12(6.15 \%)$, and ICU with $25(12.82 \%)$ cases had the top incidence, respectively.

Our study had some limitations, including, first, patients who had fungi septicemia, like Candida species, were excluded; second, the genotypic analyses were not performed to understand the clonality and epidemiology of isolates through time; and third, inadequate demographic information of patients and their underlying diseases.

\section{Conclusion}

Our study results highlight the etiological agent of septicemia and their antibiotic susceptibility pattern in this area and indicated that the most common cause of bacterial septicemia in the south of Fars province is $S$. epidermidis, A. baumannii, and E. coli. Most of the isolates were resistant to CN, FOX, and LEV respectively. High levels of resistance to common antibiotics in bacterial infection treatment were observed among the pathogens isolated from blood culture. Therefore, considering various agents that cause sepsis, different antibiotic resistance patterns, and widespread resistant organisms, periodically determining the most prevalent agents of septicemia and their antibiotic resistance pattern seems necessary. This study is helpful for clinicians to prescribe appropriate medications in the management of sepsis. Moreover, the treatment strategy via antibiotics is suggested to be reviewed due to the increasing rate of antibiotic resistance in different regions. 
Ethics

Ethics Committee Approval: The Ethics Committee of Gerash University of Medical Sciences, Gerash, Iran, approved this study with reference number IR.GERUMS. REC.1398.005.

Informed Consent: Retrospective descriptive study.

Peer-review: Externally peer-reviewed.

\section{Authorship Contributions}

Surgical and Medical Practices: A.F., A.V.L., H.H., Concept: A.F., A.V.L., H.F., J.S., I.A., P.M., Design: A.F., A.V.L., H.F., J.S., K.Z., F.F., Data Collection or Processing: A.F., A.V.L., J.S., H.H., I.A., P.M., F.F., Analysis or Interpretation: A.F., A.V.L., H.F., H.H., K.Z., Z.F., F.F., Literature Search: A.F., A.V.L., H.F., J.S., H.H., I.A., K.Z., P.M., Writing: A.F., A.V.L., H.F., J.S., H.H., I.A., K.Z., Z.F.

Conflict of Interest: No conflict of interest was declared by the authors.

Financial Disclosure: This research was supported by the grant number of Gerash 98. 000060 provided by Deputy of Research Affairs of Gerash University of Medical Sciences, Gerash, Iran.

\section{References}

1. Dagnew M, Yismaw G, Gizachew M, Gadisa A, Abebe T, Tadesse T, Tadesse T, Alemu A, Mathewos B. Bacterial profile and antimicrobial susceptibility pattern in septicemia suspected patients attending Gondar University Hospital, Northwest Ethiopia. BMC Res Notes. 2013;6:283.

2. Moradi N, Javadpoor S, Vahdani M. Prevalence and antibiogram pattern of gram negative bacteria isolated from blood cultures in Shahid mohammadi hospital Bandar Abbas. J Prev Med. 2015;2:55-61.

3. Wenzel RP, Edmond MB. The impact of hospital-acquired bloodstream infections. Emerg Infect Dis. 2001;7:174-7.

4. Laupland KB, Church DL. Population-based epidemiology and microbiology of community-onset bloodstream infections. Clin Microbiol Rev. 2014;27:647-64.

5. Cheung $Y$, Ko S, Wong OF, Lam HSB, Ma HM, Lit CHA. Clinical experience in management of bloodstream infection in emergency medical ward: A preliminary report. Hong Kong J Emerg Med. 2019;28:215-26.

6. Rabirad N, Mohammadpoor M, Lari AR, Shojaie A, Bayat R, Alebouyeh M. Antimicrobial susceptibility patterns of the gram-negative bacteria isolated from septicemia in Children's Medical Center, Tehran, Iran. J Prev Med Hyg. 2014;55:23-6.

7. Arora U, Devi P. Bacterial profile of blood stream infections and antibiotic resistance pattern of isolates. JK Sci. 2007;9:186-90.

8. Wang HY, Uh Y, Kim S, Lee H. Quantamatrix Multiplexed Assay Platform system for direct detection of bacteria and antibiotic resistance determinants in positive blood culture bottles. Clin Microbiol Infect. 2017;23:333.e1-7.

9. Gohel K, Jojera A, Soni S, Gang S, Sabnis R, Desai M. Bacteriological profile and drug resistance patterns of blood culture isolates in a tertiary care nephrourology teaching institute. Biomed Res Int. 2014;2014:153747.

10. Sherkatolabbasieh HR, Alborzi A, Pouladfar G, Shafiezadeh S, Sohrabi N. Perspective survey of frequency, features and related factors in patients with sepsis who hospitalized in Namazi Hospital, Shiraz. J Clin Res Paramed Sci 2014;3:196-204. 
11. Berkowitz FE, Jerris RC. Practical Medical Microbiology for Clinicians. New Jersey: John Wiley \& Sons; 2016.

12. Wayne P. Clinical and Laboratory Standards Institute. Performance Standards for Antimicrobial Susceptibility Testing: Twenty seven Informational Supplement M100-S27CLSI. 2019.

13. Karlowsky JA, Jones ME, Draghi DC, Thornsberry C, Sahm DF, Volturo GA. Prevalence and antimicrobial susceptibilities of bacteria isolated from blood cultures of hospitalized patients in the United States in 2002. Ann Clin Microbiol Antimicrob. 2004;3:7.

14. Khan A, Amanullah A, Hussain M, Syed A, Akbar F. Determination of antimicrobial sensitivities of different microorganisms in post surgical wound infection. J Saidu Med Coll. 2020;9:162-8.

15. Sedigh ESH, Motamedifar M, Mansury D, Halaji M, Hashemizadeh Z, Yosef AM. Bacterial etiology and antibacterial susceptibility patterns of pediatric bloodstream infections: a two year study from Nemazee Hospital, Shiraz, Iran. J Compr Pediatr. 2016;7:1-7.
16. Vaez H, Khosravi S, Soleymani E. Antibiotic resistance pattern of common etiological agents of bloodstream infections isolated from patients. Iran J Med Microbiol. 2012;5:52-8.

17. Mahmoudi H, Ghasemi Bassir HR, Hosseini SM, Arabestani MR, Alikhani MY. The frequency of bacteria isolated from blood cultures and antibiotic susceptibility patterns among admitted patients in Hospital of Hamedan University of Medical Sciences. Iran J Med Microbiol. 2016;10:69-74.

18. Dogru A, Sargin F, Celik M, Sagiroglu AE, Goksel MM, Sayhan H. The rate of device-associated nosocomial infections in a medical surgical intensive care unit of a training and research hospital in Turkey: one-year outcomes. Jpn J Infect Dis. 2010;63:95-8.

19. Japoni A, Farshad S, Alborzi A, Kalani M, Rafaatpour N, Oboodi B, Pourabbas B. Epidemiology and antibacterial susceptibility patterns of bloodstream infections, 2001-2004: an experience with BACTEC 9240 in Southern Iran. Pak J Biol Sci. 2008;11:422-7. 